\title{
The Effect of Lycopene Addition on the Chemical Composition, Sensory Attributes and Physicochemical \\ Properties of Steamed and Grilled Turkey Breast
}

-Author(s)

\author{
Skiepko N' \\ Chwastowska-Siwiecka I' \\ Kondratowicz \\ Mikulski D"
}

Department of Commodity Science and Animal Raw Material Processing, Faculty of Animal Bioengineering, University of Warmia and Mazury, Oczapowskiego 5, 10-719 Olsztyn, Poland,

" Department of Poultry Science, Faculty of Animal Bioengineering, University of Warmia and Mazury, Oczapowskiego 5, 10-719 Olsztyn, Poland

\section{nail Address}

Corresponding author e-mail address Natalia Skiepko

Department of Commodity Science and Animal Raw Material Processing

Faculty of Animal Bioengineering University of Warmia and Mazury

Oczapowskiego 5

10-719 Olsztyn, Poland

E-mail: natalia.skiepko@uwm.edu.pl

\section{EKeywords}

Carotenoids, lycopene, poultry, quality of meat, final product.

\section{ABSTRACT}

The aim of this study was to determine the effect of lycopene addition to the curing mixture for steamed and grilled breast muscles on the chemical composition, sensory attributes and physicochemical parameters of the final products. The experimental material comprised a total of 48 breast muscles of Hybrid XL turkeys aged 15 weeks and fed commercial pelleted diets. The material was divided into three groups (control, experimental groups I and II). Sixteen breast muscles (8 left and 8 right) were assigned to each group. Control group samples were immediately transported to a laboratory. The remaining 32 muscles were steamed and grilled, where 16 samples were cured before heat treatment. The curing brine contained tomato peel extract standardized for $5 \%$ lycopene content. The results of the study indicate that the lycopene increased vitamin E levels and decreased the ash and vitamin A content of the final products. Lycopene also lowered the aroma and flavour scores, and increased the shear force values of the final products. The addition of lycopene lowered the $\mathrm{pH}$ of the products measured in a water homogenate and deteriorated the hydration properties of meat. Lycopene increased the darkness and the contribution of redness, which led to an increase in colour saturation and hue values of the evaluated samples. It can be concluded that lycopene exerted antioxidant effects and improved the colour parameters on the external surface and along the cross-section of processed meat. However, the specific flavour of tomatoes deteriorated the sensory attributes of the final products.

\section{INTRODUCTION}

Technological progress supports the use of novel food components in food processing to enhance the nutritional value of food products and deliver health benefits for consumers. The growing popularity of health-promoting foods could create a demand for foods enhanced with carotenoids (Shi \& Maguer, 2000). Carotenoids are pigments that are widely distributed in nature and are responsible for the attractive colouring of fruit and vegetables (Maiani et al., 2009; Doménech-Asensi et al., 2013). Natural carotenoid extracts and chemically synthesized carotenoids are added to numerous food products, beverages and feed for farm animals. Carotenoids have the same chemical reactivity in the human body as in plants; therefore, they are able to capture free radicals and atomic oxygen, and protect the body against oxidative stress. Carotenoids prevent cardiovascular diseases, they have anticarcinogenic properties, they control immune functions and are precursors of vitamin A (Rao et al., 1999; Xu et al., 2006; Maiani et al., 2009; Doménech-Asensi et al., 2013).

Lycopene ( $\psi, \psi$-carotene) is the red pigment in fruit and vegetables, and it is particularly abundant in tomatoes (Lycopersicon esculentum 
Mill.), where it accounts for $80-90 \%$ of all pigments (Doménech-Asensi et al., 2013). The tomato processing industry generates large quantities of byproducts (mainly seeds and peels) which, if discarded, have a negative environmental impact and have to be neutralized (Vági et al., 2007; Calvo et al., 2008; García et al., 2009). By-products have a high lycopene content, therefore they may be an attractive alternative to the reuse of tomato residues, providing a cheap source of this carotenoid (Papaioannou \& Karabelas, 2012). Lycopene is resistant to heat processing such as boiling in water, steaming, microwaving and braising. When tomatoes are heat processed, lycopene is converted into a form that is more readily absorbed from the human gastrointestinal tract. Advanced food processing methods can significantly improve the bioavailability of lycopene (Chen et al., 2009).

Studies conducted to date investigated the effects of different forms of lycopene on the nutritional value, physicochemical properties and sensory quality of cured meats. According to Østerlie \& Lerfall (2005) and García et al. (2009), lycopene efficiently decreases lipid oxidation and successfully stabilizes the red colour of minced meat and hamburger patties during the storage period. The addition of lycopene decreases the $\mathrm{pH}$ of meat products, thus slowing down microbial growth in meat products. Calvo et al. (2008) demonstrated that dry fermented sausages enriched with lycopene from tomato peel were characterized by the lowest lightness. The cited authors also concluded that the sensory and textural properties and overall acceptability of all analyzed sausages were satisfactory. Eyiler \& Oztan (2011) reported that dried tomatoes in powder form protected frankfurters against oxidation and contributed to their higher lipid and colour stability. The addition of lycopene has also been studied in mortadellas (Doménech-Asensi et al., 2013), pork luncheon rolls (Hayes et al., 2013) and beef patties (Sánchez-Escalante et al., 2003), whereas there are no published data on the effects of lycopene on the quality of turkey meat products. In studies of oxidative stability, chemical composition and colour of poultry meat and eggs, most experiments involved the addition of $\psi, \psi$-carotene in powder form to diets for broilers (Englmaierová et al., 2011), laying hens (Karadas et al., 2006a; Akdemir et al., 2012) and quails (Karadas et al., 2006b). In view of the above, the aim of the present study was to determine the effect of lycopene addition to the curing brine for steamed and grilled turkey breast muscles on the proximate chemical composition, vitamin content, sensory quality and physicochemical properties of the final products.

\section{MATERIALS AND METHODS}

\section{Birds, diets and experimental design}

The experiment was performed at the Research Laboratory of the Department of Poultry Science of the University of Warmia and Mazury in Olsztyn, Poland. All experimental procedures had been approved by the Local Ethics Committee for Animal Experimentation of the University of Warmia and Mazury in Olsztyn, Poland (Prot. 103/2013/N).

The experimental material included 211 oneday-old female Hybrid XL turkeys purchased at the "Grelavi" Hatchery in Kętrzyn (Poland). Throughout the experiment, i.e. until 15 weeks of age, the birds had ad libitum access to commercial pelleted feed (Table 1), prepared in line with a nutritional program developed by the AGROCENTRUM feed mill in Kolno (Poland). All birds were kept under identical housing and sanitary conditions with ad libitum access to water from automatic drinkers. Turkeys (24 birds at the age of 15 weeks) weighing approximately $10 \mathrm{~kg}$ were slaughtered, and carcasses were dissected with the use of industrial methods in accordance with

Table 1 - Ingredients and chemical composition of the basal diet.

\begin{tabular}{|c|c|}
\hline Ingredient & $(\mathrm{g} / \mathrm{kg})$ \\
\hline Wheat & 671.9 \\
\hline Soybean meal & 264.1 \\
\hline Soybean oil & 8.0 \\
\hline Linseed oil & 27.0 \\
\hline Sodium bicarbonate & 1.0 \\
\hline Salt & 1.4 \\
\hline Limestone & 12.1 \\
\hline Monocalcium phosphate & 5.2 \\
\hline Phytase $^{1}$ & 0.1 \\
\hline Xylanase ${ }^{2}$ & 0.2 \\
\hline DL-Methionine & 0.9 \\
\hline L-Lysine & 3.4 \\
\hline L-Threonine & 0.7 \\
\hline Vitamin-mineral premix & 4.0 \\
\hline \multicolumn{2}{|l|}{ Chemical analyses } \\
\hline Metabolisable energy (kcal/kg) & 3000 \\
\hline Crude protein & 205.0 \\
\hline Lysine & 12.0 \\
\hline Methionine & 3.8 \\
\hline Methionine+cystine & 7.5 \\
\hline $\mathrm{Ca}$ & 7.5 \\
\hline Available P & 3.0 \\
\hline $\mathrm{Na}$ & 1.0 \\
\hline
\end{tabular}


technological and sanitary standards applicable to the poultry industry (EC, 2009). Carcasses were chilled in the FROST refrigerating unit at $4 \pm 1^{\circ} \mathrm{C}$ and relative humidity of approximately $85 \%$ for 24 hours (EC, 2004). $\mathrm{pH}_{15}$ and $\mathrm{pH}_{24}$ values were determined after slaughter in the left and right breast muscles of each carcass (PN-ISO, 2002).

The analyzed material comprised a total of 48 breast muscles (musculus pectoralis major), 24 left and 24 right, weighing approximately $1 \mathrm{~kg}$ each, which were obtained from 24 randomly sampled turkeys. The material was divided into three groups (a control group, experimental group I and experimental group II). Sixteen breast muscles (8 left muscles and 8 right muscles) were assigned to each group. Control group samples were immediately transported to a laboratory. Sixteen muscles from experimental group I were placed on a iron grid and were heat treated (stage 1 and 2) in the UNOX S.p.A. ChefTop XVC305 convection steam oven (Padova, Italy). Heat treatment conditions were consistent with those described by Litwińczuk et al. (2004) and with the device's programmable parameters. At the first stage of heat treatment, oven temperature was set to $120^{\circ} \mathrm{C}$ and humidity was set to $60 \%$ until the temperature inside the product reached $70^{\circ} \mathrm{C}$. At the second stage, meat samples were grilled for 8 minutes at $230^{\circ} \mathrm{C}$ with $60 \%$ dehydration. The remaining 16 breast muscles from experimental group II were cured (for 3 days at $8 \pm 1^{\circ} \mathrm{C}$ ) in curing vats with a clamp grate, filled with a curing brine composed of tomato peel extract standardized for $5 \%$ lycopene content and purchased from a local supplier (0.27\%), water (97.94\%), salt (1.29\%), glucose $(0.15 \%)$, ground black pepper $(0.05 \%)$, whole black peppercorns $(0.05 \%)$, bay leaf $(0.02 \%)$, allspice $(0.08 \%)$, marjoram $(0.03 \%)$ and garlic $(0.12 \%)$. After three days, cured muscles were placed on a iron grid, steamed and grilled under identical conditions as experimental group I samples. Immediately after heat treatment, all samples (experimental groups I and II) were cooled to a temperature of $8-12^{\circ} \mathrm{C}$ inside the product, and were stored for $24 \mathrm{~h}$ at $4 \pm 1^{\circ} \mathrm{C}$.

Raw breast muscles (control group) and both types of steamed and grilled muscles (experimental groups I and II) were subjected to quantitative and qualitative analyses at the Laboratory for Meat Quality Evaluation of the Department of Commodity Science and Processing of Animal Raw Materials and the Department of Animal Nutrition and Feed Science of the University of Warmia and Mazury in Olsztyn, Poland.

\section{Determination of chemical composition}

The following parameters were determined in a proximate analysis of ground meat samples: dry matter content (PN-ISO, 2000b), total protein content by the Kjedahl method (PN-A, 2002) in the FOSS Tecator Kieltec 2200 System I, fat content by the Soxhlet method (PN-ISO, 2000c) in the FOSS Tecator Soxtec ${ }^{\mathrm{TM}}$ Avanti 2050 extractor, and ash content (PNISO, 2000a). The hydroxyproline content of meat and meat products (PN-ISO, 2000d) was also determined, which provided the basis for calculating total collagen content with the use of the 7.25 conversion factor proposed by Palka (1999). Vitamin E ( $\alpha$-tocopherol) and vitamin A (total retinol) concentrations were determined by reverse-phase high-performance liquid chromatography (HPLC) in a SHIMADZU chromatograph using the method described by Hőbgerg et al. (2002), Fredriksson Eriksson \& Pickova (2007), and Xu (2008). The Nucleosil $C_{18}$ column was used, and methanol in aqueous solution ( $\mathrm{v} / \mathrm{v}$ 95:5) was the carrier phase. Measurements were carried out with a fluorescent detector (excitation wavelength of $295 \mathrm{~nm}$, emission wavelength of $330 \mathrm{~nm}$ ). Tocopherol and retinol concentrations were calculated based on peak areas using external standards (SIGMAALDRICH: ( \pm )- $\alpha$-Tocopherol, Retinol Vitamin-A-alcohol) (Koprivnjak et al., 1996; Gimeno et al., 2000).

\section{Physicochemical properties}

In the left and right breast muscles, $\mathrm{pH}$ was measured 15 minutes post mortem and after 24 of refrigeration using the 340 i pH-meter with the WTW TFK 150/E temperature sensor and the Hamilton Double Pore combination electrode. A water homogenate with 1:1 sample-to-redistilled water ratio was prepared to determine the $\mathrm{pH}_{u}$ of chilled breast muscles and final products. The $\mathrm{pH}$ of samples was measured with the use of the above $\mathrm{pH}$-meter which was calibrated with standard buffer solutions with a known pH (PN-ISO, 2002).

Natural drip loss (Honikel, 1998) in raw breast muscles was determined by suspending a weighed meat sample of approximately $20-30 \mathrm{~g}$ in a zip-lock bag (PE) in an incubator at $4 \pm 1^{\circ} \mathrm{C}$. After 24 hours, the sample was weighed again and drip loss (\%) was calculated as the difference in weight before and after refrigeration. Thermal loss (Honikel, 1998) was determined by pasteurizing a weighed meat sample of approximately $70-100 \mathrm{~g}$ in a zip-lock bag (PE) in a water bath at $75^{\circ} \mathrm{C}$ for 50 minutes. The samples were cooled for 30 minutes under a stream of running 
cold water, dried and weighed. Thermal loss (\%) was determined as the difference in sample weight before and after heat treatment. The water-holding capacity of raw breast muscles and processed meat products was determined as described by Grau and Hamm (Van Oeckel et al., 1999) by placing a sample of ground meat (approximately $300 \mathrm{mg}$ ) on Whatman Grade No. 1 filter paper. Filter paper and the sample were placed between two glass plates and subjected to a load of 5 $\mathrm{kg}$ for 5 minutes. The meat area and the expressed juice area were outlined and measured with a planimeter. The difference between both areas was an indication of forced drip loss, and it was recalculated to $0.3 \mathrm{~g}$ as a measure of water-holding capacity $\left(\mathrm{cm}^{2}\right)$. Cooking loss was calculated by weighing meat before and after heat treatment, on a Radwag weighing scale accurate to $0.01 \mathrm{~g}$. The result was expressed as a percentage of initial weight.

The shear force of chilled breast muscles was determined in samples from the cooking loss analysis which were wrapped in aluminium foil and stored at $4 \pm 1^{\circ} \mathrm{C}$ for $24 \mathrm{~h}$. Samples of processed muscles were collected immediately after heat treatment and were stored under identical conditions. Five cylindrical specimens, $1.27 \mathrm{~cm}$ in diameter and $2 \mathrm{~cm}$ in height, were cut out from each sample. The specimens were cut against the grain in the INSTRON 5542 universal testing machine equipped with a Warner-Bratzler head (500 N, speed of $100 \mathrm{~mm} / \mathrm{min}$ ). The maximum force required to cut the specimens was registered.

The colour of raw breast muscles and processed meat products was determined with a colorimeter, and the values were expressed in terms of CIE LAB coordinates $L^{*}, a^{*}, b^{*}, C^{*}(C I E, 1978)$ by the reflectance method using the MiniScan XE Plus instrument (HunterLab), applying the angle of the CIE standard observer and standard illuminant $\mathrm{D}_{65} / 10^{\circ}$ Measurements were performed in three replications along the cross-section of raw breast muscles, on the external surface and along the cross-section of the final products. Colour saturation (chroma), hue and total colour difference were calculated using the Equations 1 and 2 (Hunt et al., 1991):

$$
\begin{aligned}
& \mathrm{C}^{\star}=\sqrt{a^{2}+b^{2}}, \mathrm{~h}^{\circ}=\tan ^{-1}(\mathrm{~b} / \mathrm{a}) \\
& \Delta \mathrm{E}=\sqrt{(\Delta L)^{2}+(\Delta a)^{2}+(\Delta b)^{2}}
\end{aligned}
$$

\section{Sensory attributes}

A sensory evaluation of chilled muscles (control group) was performed as described by Baryłko-Pikielna
\& Matuszewska (2009). Samples of approximately 50 $\mathrm{g}$ were cut out across the grain and cooked in $0.6 \%$ $\mathrm{NaCl}$ solution (2:1 solution-to-meat ratio) at $96 \pm 2^{\circ} \mathrm{C}$ until the temperature inside the sample reached $80^{\circ} \mathrm{C}$. Samples of final products (group I and II) were collected directly without heat processing. All samples were coded and evaluated by panellists ( 3 females and 2 male) from the University of Warmia and Mazury (Olsztyn, Poland), aged between 30 and 40 years. All panellists were trained in accordance with ISO (1994) standards, and were experienced in sensory assessments of different food products. The panel room was provided with sufficient light, protected from noise and extraneous odours to prevent the influence of external factors (ISO, 1998). A small session before the evaluation was made with the panellists in order for them to become familiar with the evaluation. Unsalted crackers and room temperature water were also provided to clean the palate between samples. One sample of each product (a total of 48 samples) was served to the assessors. The panellists were asked to score aroma (desirability and intensity), juiciness, tenderness and flavour (desirability and intensity), using a 5-point grading scale with half points (PN-ISO, 1998), where 5 points was the most satisfactory score, and 1 point was the least satisfactory score.

\section{STATISTICAL ANALYSES}

Mean values, standard deviations (SD) and standard errors of the mean (SEM) were computed. Differences in the quality between turkey breast muscles subjected to various treatments were determined by one-way analysis of variance. The significance of differences between processed meat products was determined by Duncan's test using Statistica 10 program (StatSoft Inc., 2011).

\section{RESULTS}

\section{Quality of chilled turkey breast muscles}

The chemical composition, sensory attributes and physicochemical properties of chilled turkey breast muscles are presented in Table 2. The dry matter content of samples chilled for 24 hours was determined as $26.23 \%$ in the proximate analysis. Protein content was relatively high (24.25\%), whereas fat and ash levels approximated domestic norms $(1.21 \%$ and $1.15 \%$, respectively). The average collagen content of muscle tissue was calculated from the hydroxyproline assay as $0.93 \mathrm{mg} / \mathrm{g}$. The vitamin E content of chilled muscles was $1.07 \mu \mathrm{g} / \mathrm{g}$ higher than vitamin A content $(0.07 \mu \mathrm{g} / \mathrm{g})$. 
The analysed meat samples (control group) received 4.28 to 4.66 points on a 5 -point grading scale in a sensory evaluation (Table 2), and the results testify to the high quality of the evaluated meat. Turkey breast muscles received one of the highest scores for aroma desirability and intensity (4.66 and 4.59 points, respectively). The analysed samples from the control group were also characterised by highly satisfactory juiciness, and scored 4.63 points on average in this category. Tenderness was also evaluated highly at 4.34 points. Flavour intensity and desirability scored 4.30 points on average. The average shear force was determined at $11.42 \mathrm{~N}$ with the use of instrumental methods, and it corresponded to the score awarded by panellists.

Table 2 data show that control group samples were characterized by normal acidity. $\mathrm{pH}$ measured 15 minutes and 24 hours after slaughter reached 6.11 and 5.73 , respectively. The decrease in $\mathrm{pH}$ values noted 24

Table 2 - Chemical composition, sensory quality, shear force values and physicochemical properties of chilled turkey breast muscles (mean $\pm S D^{1}$ ).

\begin{tabular}{|c|c|}
\hline Specification & $\begin{array}{l}\text { Control group } \\
(n=16)\end{array}$ \\
\hline \multicolumn{2}{|l|}{ Chemical composition } \\
\hline Dry matter (\%) & $26.23 \pm 0.77$ \\
\hline Crude protein (\%) & $24.25 \pm 0.62$ \\
\hline Crude fat (\%) & $1.21 \pm 0.07$ \\
\hline Crude ash (\%) & $1.15 \pm 0.02$ \\
\hline Total collagen (mg/g wet tissue) & $0.93 \pm 0.31$ \\
\hline Vitamin E ( $\mu \mathrm{g} / \mathrm{g})$ & $1.14 \pm 0.21$ \\
\hline Vitamin A $(\mu \mathrm{g} / \mathrm{g})$ & $0.07 \pm 0.02$ \\
\hline \multicolumn{2}{|l|}{ Sensory quality and shear force } \\
\hline Aroma- intensity (points) & $4.59 \pm 0.42$ \\
\hline Aroma- desirability (points) & $4.66 \pm 0.35$ \\
\hline Juiciness (points) & $4.63 \pm 0.42$ \\
\hline Tenderness (points) & $4.34 \pm 0.48$ \\
\hline Flavour- intensity (points) & $4.31 \pm 0.75$ \\
\hline Flavour- desirability (points) & $4.28 \pm 0.73$ \\
\hline Shear force value $(\mathrm{N})$ & $11.42 \pm 1.51$ \\
\hline \multicolumn{2}{|l|}{ Physicochemical properties } \\
\hline $\mathrm{pH}_{15}$ & $6.11 \pm 0.21$ \\
\hline $\mathrm{pH}_{24}$ & $5.73 \pm 0.08$ \\
\hline $\mathrm{pH}_{\mathrm{u}}$ & $5.70 \pm 0.09$ \\
\hline Drip loss (\%) & $0.67 \pm 0.07$ \\
\hline Thermal loss (\%) & $21.14 \pm 0.77$ \\
\hline Water holding capacity $\left(\mathrm{cm}^{2}\right)$ & $4.59 \pm 0.70$ \\
\hline Lightness $\left(L^{*}\right)$ & $56.36 \pm 0.94$ \\
\hline Redness (a*) & $5.06 \pm 0.36$ \\
\hline Yellowness $\left(b^{\star}\right)$ & $10.64 \pm 0.83$ \\
\hline Saturation $\left(C^{*}\right)$ & $11.78 \pm 0.85$ \\
\hline Hue $\left(h^{\circ}\right)$ & $64.54 \pm 1.42$ \\
\hline
\end{tabular}

${ }^{1} \mathrm{SD}=$ Standard deviation hours after slaughter indicates that glycolysis processes were normal in the breast muscles. The average $\mathrm{pH}$ of the water homogenate was 5.70, which further testified to the normal acidity of meat samples. Natural drip loss was relatively low at $0.67 \%$, whereas thermal loss was high at $21.14 \%$. Water-holding capacity, which describes the meat's ability to retain inherent and added water, was determined at $4.59 \mathrm{~cm}^{2}$ on average.

The colour parameters of chilled meat samples are presented in Table 2. Poultry meat is generally regarded as white meat, and the analyzed samples were characterized by high lightness values (56.36). The red component of meat was determined at 5.06 and the $b$ * component- at 10.64. The colour saturation (chroma) of chilled muscles was fairly stable, the value of coordinate $C^{*}$ was determined at 11.78 and hue- at 64.54

\section{Quality of heat-treated turkey breast muscles}

A proximate analysis of the final products (Table 3) revealed that the ash content of cured meat samples $(1.11 \%)$ was significantly lower $(p \leq 0.01)$ in comparison with uncured muscles (1.22\%). No significant differences were noted in dry matter, protein and fat content. Total collagen concentrations in both experimental groups were similar at $0.77 \mathrm{mg} / \mathrm{g}$ muscle tissue on average. Meat cured with the addition of lycopene was characterized by a highly significantly higher $(p \leq 0.01)$ vitamin $E$ content $(1.05 \mu \mathrm{g} / \mathrm{g})$ and $a$ significantly lower $(p \leq 0.05)$ vitamin $A$ content $(0.02$ $\mu \mathrm{g} / \mathrm{g}$ ).

A sensory analysis of processed meat products (Table 3) from experimental groups (I and II) revealed that uncured steamed and grilled samples were characterised by higher quality than cured samples. The most significant differences $(p \leq 0.01)$ between the above groups were noted in aroma desirability and intensity. Products without added lycopene received an average of 4.77 and 4.82 points for aroma desirability and intensity, respectively. Tenderness and juiciness were similar in both groups, scoring 4.22 and 4.26 points, respectively, on average. In uncured and heattreated muscles, flavour intensity was higher by 0.34 points $(p \leq 0.01)$ and flavour desirability was higher by 0.39 points in comparison with other samples. Instrumentally measured tenderness was higher in cured samples $(17.17 \mathrm{~N})$, and the observed differences were statistically significant $(p \leq 0.01)$. Products with added lycopene were characterised by satisfactory sensory quality despite lower scores. 
Table 3 - Chemical composition, sensory quality and shear force values of heat-treated turkey breast muscles (mean $\pm S D^{\prime}$ ).

\begin{tabular}{|c|c|c|c|c|}
\hline \multirow[b]{2}{*}{ Specification } & \multicolumn{2}{|c|}{ Technological group } & \multirow[b]{2}{*}{$\mathrm{SEM}^{2}$} & \multirow[b]{2}{*}{ Group effect } \\
\hline & $\begin{array}{c}\text { I } \\
\text { Uncured muscles } \\
(n=16)\end{array}$ & $\begin{array}{l}\| \\
\text { Cured muscles with added lycopene } \\
(n=16)\end{array}$ & & \\
\hline \multicolumn{5}{|l|}{ Chemical composition } \\
\hline Dry matter (\%) & $33.33 \pm 0.72$ & $33.70 \pm 1.10$ & 0.21 & ns \\
\hline Crude protein (\%) & $31.31 \pm 0.67$ & $31.34 \pm 1.25$ & 0.22 & ns \\
\hline Crude fat (\%) & $1.05 \pm 0.07$ & $1.07 \pm 0.05$ & 0.01 & ns \\
\hline Crude ash (\%) & $1.22 \pm 0.03$ & $1.11 \pm 0.02$ & 0.01 & ** \\
\hline Total collagen (mg/g wet tissue) & $0.74 \pm 0.08$ & $0.79 \pm 0.17$ & 0.04 & ns \\
\hline Vitamin $E(\mu \mathrm{g} / \mathrm{g})$ & $0.77 \pm 0.08$ & $1.05 \pm 0.06$ & 0.04 & $* *$ \\
\hline Vitamin A $(\mu \mathrm{g} / \mathrm{g})$ & $0.03 \pm 0.01$ & $0.02 \pm 0.00$ & 0.00 & * \\
\hline \multicolumn{5}{|l|}{ Sensory quality and shear force } \\
\hline Aroma- intensity (points) & $4.77 \pm 0.12$ & $3.99 \pm 0.37$ & 0.11 & ** \\
\hline Aroma- desirability (points) & $4.82 \pm 0.12$ & $3.90 \pm 0.37$ & 0.12 & ** \\
\hline Juiciness (points) & $4.43 \pm 0.46$ & $4.08 \pm 0.49$ & 0.11 & ns \\
\hline Tenderness (points) & $4.34 \pm 0.39$ & $4.09 \pm 0.49$ & 0.10 & ns \\
\hline Flavour- intensity (points) & $4.59 \pm 0.31$ & $4.25 \pm 0.19$ & 0.07 & ** \\
\hline Flavour- desirability (points) & $4.61 \pm 0.30$ & $4.22 \pm 0.22$ & 0.07 & ** \\
\hline Shear force value $(N)$ & $11.71 \pm 1.20$ & $17.17 \pm 1.62$ & 0.70 & ** \\
\hline
\end{tabular}

* Mean values denoted by different letters in the row are statistically significantly different at $p \leq 0.05$;

** Mean values denoted by different letters in the row are statistically significantly different at $p \leq 0.01$;

${ }^{1} \mathrm{SD}=$ Standard deviation

${ }^{2} \mathrm{SEM}=$ Standard error of the mean

$\mathrm{ns}=$ not significant;

The physicochemical properties of final products are presented in Table 4. The products from experimental group II were characterised by a significantly lower $(p \leq 0.05)$ average value of $\mathrm{pH}_{u}$ (by 0.06$)$ that group I samples. Group II products were also characterised by less $(p \leq 0.05)$ satisfactory water-holding capacity which was $0.84 \mathrm{~cm}^{2}$ higher than in group I. Curing with the addition of lycopene increased weight loss during heat treatment $(p \leq 0.01)$. Average weight loss during steaming and grilling was determined at $27.98 \%$ on average in uncured samples and at $31.08 \%$ in group Il samples.

The results presented in Table 4 indicate that uncured meat products (group I) were characterised by a significantly lighter $(p \leq 0.01)$ colour on the surface (by 9.32) and across the cross-section (by 4.34) than cured meat products. In group II samples, a higher contribution of redness $(p \leq 0.01)$ and higher values of coordinate $C$ * were observed in both examined planes in comparison with uncured samples. The value of component $b$ * on the surface was similar in the examined groups at 27.86 on average, but it was highly significantly higher $(p \leq 0.01)$ along the cross-section in cured samples with added lycopene (by 1.99). Parameter $h^{\circ}$ values were higher $(p \leq 0.01)$ in both analysed planes in uncured muscles (74.40 on the surface, 82.98 along the cross- section). The average values of $\Delta \mathrm{E}$ on the surface of meat samples indicate that cured products with added lycopene were characterised by greater colour stability. In those samples, the value of total colour difference on the surface was higher by 7.32 in comparison with uncured samples, and the noted difference was statistically significant $(p \leq 0.01)$. An inversely proportional correlation was reported along the crosssection of the analysed samples. Cured muscles with added lycopene (group II) were characterised by a significantly lower $(p \leq 0.01)$ value of $\Delta E$, at 16.54 . The curing brine with added lycopene significantly influenced the physicochemical properties of final products.

\section{DISCUSSION}

An analysis of the results of this study supported an evaluation of chilled turkey breast muscles, which were processed into two types of final products. A comparison with other studies indicates that the analysed meat samples were characterised by satisfactory chemical composition (Werner et al., 2008; Lipiński et al., 2011; Mikulski et al., 2012). According to the panellists, turkey breast muscles were also characterised by high sensory quality and shear force values indicative of satisfactory 
Table 4 - Physicochemical properties of heat-treated turkey breast muscles (mean \pm SD'1).

\begin{tabular}{|c|c|c|c|c|}
\hline \multirow[b]{2}{*}{ Specification } & \multicolumn{2}{|c|}{ Technological group } & \multirow[b]{2}{*}{$\mathrm{SEM}^{2}$} & \multirow[b]{2}{*}{ Group effect } \\
\hline & $\begin{array}{c}\text { I } \\
\text { Uncured muscles } \\
(n=16)\end{array}$ & $\begin{array}{c}\| \\
\text { Cured muscles with added lycopene } \\
(n=16)\end{array}$ & & \\
\hline $\mathrm{pH}_{\mathrm{u}}$ & $5.85 \pm 0.05$ & $5.79 \pm 0.05$ & 0.01 & * \\
\hline Cooking loss (\%) & $27.98 \pm 1.15$ & $31.08 \pm 1.27$ & 0.44 & ** \\
\hline Water holding capacity $\left(\mathrm{cm}^{2}\right)$ & $4.83 \pm 0.84$ & $5.67 \pm 0.46$ & 0.18 & * \\
\hline \multicolumn{5}{|l|}{ Colour onthe surface } \\
\hline Lightness $\left(L^{*}\right)$ & $67.83 \pm 0.47$ & $58.51 \pm 0.35$ & 0.45 & ** \\
\hline Redness $\left(a^{\star}\right)$ & $7.55 \pm 0.98$ & $18.79 \pm 0.41$ & 0.29 & ** \\
\hline Yellowness $\left(b^{*}\right)$ & $27.35 \pm 0.34$ & $28.36 \pm 0.77$ & 0.57 & ns \\
\hline Saturation $\left(C^{\star}\right)$ & $28.46 \pm 0.71$ & $32.47 \pm 0.33$ & 0.44 & ** \\
\hline Hue $\left(h^{\circ}\right)$ & $74.40 \pm 0.76$ & $64.39 \pm 0.57$ & 0.49 & ** \\
\hline$\Delta \mathrm{E}$ & $16.40 \pm 0.75$ & $23.72 \pm 0.62$ & 0.56 & ** \\
\hline \multicolumn{5}{|c|}{ Colour along the cross-section } \\
\hline Lightness $\left(L^{*}\right)$ & $80.41 \pm 1.65$ & $76.07 \pm 1.04$ & 0.58 & ** \\
\hline Redness $\left(a^{*}\right)$ & $1.78 \pm 0.14$ & $2.53 \pm 0.17$ & 0.09 & ** \\
\hline Yellowness $\left(b^{*}\right)$ & $14.45 \pm 0.63$ & $16.44 \pm 0.54$ & 0.27 & ** \\
\hline Saturation $\left(C^{*}\right)$ & $14.75 \pm 0.82$ & $16.64 \pm 0.68$ & 0.27 & ** \\
\hline Hue $\left(h^{\circ}\right)$ & $82.98 \pm 0.61$ & $81.26 \pm 0.41$ & 0.23 & * \\
\hline$\Delta \mathrm{E}$ & $22.51 \pm 0.43$ & $16.54 \pm 0.55$ & 0.38 & ** \\
\hline
\end{tabular}

* Mean values denoted by different letters in the row are statistically significantly different at $p \leq 0.05$;

${ }^{* *}$ Mean values denoted by different letters in the row are statistically significantly different at $p \leq 0.01$;

${ }^{1} \mathrm{SD}=$ Standard deviation

${ }^{2} \mathrm{SEM}=$ Standard error of the mean

ns = not significant;

tenderness. However, in a study by Kondratowicz et al. (2011), chilled muscles received higher scores in a sensory evaluation. Mikulski et al. (2012) reported a higher shear force value $(19.10 \mathrm{~N})$ in the breast muscles of control group turkeys. In our study, selected physicochemical properties (acidity, hydration) of turkey breast meat were similar to those noted by Batkowska \& Brodacki (2011). In their experiment, the $\mathrm{pH}_{24}$ value of breast muscles from BIG 6 turkeys fed standard diets was determined at 5.61, water-holding capacity - at $3.12 \mathrm{~cm}^{2}$, and thermal loss - at $19.62 \%$. Only natural drip loss was significantly higher (by $0.42 \%$ ) than that noted in our study, which could result from different methodological assumptions, including the fact that the parameter was determined after a longer time (after 48 h). Zybert et al. (2015) and Sieczkowska et al. (2013) demonstrated that natural drip loss from pork was higher when measured after longer periods of time (48, 96 and 144 h). According to Wilkanowska (2011), fresh meat evaluated immediately after slaughter is characterized by optimal hydration, which deteriorates with decreasing $\mathrm{pH}$, with progress in glycolysis and rigor mortis. The lightness of chilled turkey meat determined in our study (56.36) was similar to the value reported by Mikulski et al. (2012) in a group of birds fed a diet without the addition of rapeseed meal (55.09). The meat analysed by the cited authors had a higher contribution of redness (by 3.49) and yellowness (by 4.41), in comparison with the values obtained in our experiment (5.06 and 10.64, respectively). In our opinion, the differences in the quality of chilled turkey breast muscles analysed in our experiment and in studies by other authors could be attributed to differences in bird type (medium-heavy, heavy), diet, slaughter conditions and post-slaughter handling.

The addition of lycopene during processing of turkey breast muscles did not lead to changes in dry matter, protein, fat or total collagen content of meat, but it contributed to a decrease in ash content. According to Savadkoohi et al. (2014), tomato pomace can be classified as a rich source of fibre and protein. However, the above authors did not note significant changes in the chemical composition of beef frankfurters after the addition of $1 \%$ tomato pomace to the stuffing. When tomato pomace was added at 3, 5 and $7 \%$, significant differences were observed in the concentrations of protein, fat, ash and water. The absence of significant differences in the majority of chemical components in our study could be due to a too low inclusion level of 
lycopene in powder form. The decrease in ash content could result from the fact that turkey muscles were cured by covering in brine. Contradictory findings were reported by Doménech-Asensi et al. (2013), in whose study, changes in the protein content of mortadella were inversely proportional to increasing inclusion levels of tomato paste. In both experimental groups, protein content decreased from $18.01 \%$ to $12.54 \%$ and from $12.93 \%$ to $10.43 \%$, whereas no differences were observed in the content of fat, ash or water. According to Hayes et al. (2013), increased concentrations of tomato pulp powder added during the production of pork luncheon rolls reduced water content and increased dry matter content during all analysed periods of cold storage. The addition of tomato pulp powder had no significant effect on total protein content, as average protein concentrations ranged from $11.2 \%$ to $11.6 \%$. The cited authors did not explain the reasons for the above changes, but we believe that protein content could have been stabilised by the addition of soybean protein in the production process of pork luncheon rolls. Candogan (2002) analysed beef patties containing different amounts of tomato paste (5, 10 and 15\%). No differences in water, protein or ash content were observed between products containing $5 \%$ and $10 \%$ tomato paste. The addition of $15 \%$ tomato paste increased water and ash content, but lowered protein levels $(p<0.05)$ in comparison with the control group. Beef patties containing $10 \%$ and $15 \%$ tomato paste were characterised by a significantly lower $(p<0.05)$ fat content (by $1.19 \%$ and $1.72 \%$, respectively) relative to control samples (14.53\%). In our study, a considerable increase in vitamin E levels and a decrease in vitamin A concentrations were observed. It seems that changes in vitamin concentrations can be attributed to the antioxidant properties of lycopene. However, this hypothesis cannot be validated due to the lack of data on the effect of lycopene on the vitamin content of cured meats. The results of experiments in which poultry diets were supplemented with lycopene are inconclusive with regard to the quality of raw meat. According to Rozbicka-Wieczorek et al. (2014), feed supplemented with lycopene (Lyc) most effectively stimulated $\alpha$-tocopherol $(\alpha-T)$ accumulation in the thigh muscles of chickens, in comparison with fish oil and selenium in the form of sodium selenate or selenium yeast. $\alpha$-T concentrations in the meat of birds fed Lyc reached $2.79 \mu \mathrm{g} / \mathrm{g}$, and were $0.74 \mu \mathrm{g} / \mathrm{g}$ higher than in the control group. Englmaierová et al. (2011) analysed antioxidants added to broiler chicken diets and found that lycopene significantly decreased $(p=$ $0.002) \alpha$-tocopherol levels and increased $(p<0.001)$ the vitamin A content of thigh muscles.

The addition of lycopene to the curing mixture significantly contributed to undesirable changes in aroma, flavour and instrumentally measured tenderness of processed meat products. Eyiler \& Oztan (2011) lowered nitrite levels and increased the content of tomato powder to improve the sensory attributes of frankfurters. The consumers often choose food products based on colour as a primary quality parameter. The internal and external colour of frankfurters containing tomato powder was more acceptable by consumers, both in cooked and uncooked samples. The increase in tomato powder content led to a decrease $(p<0.05)$ in the tenderness of raw frankfurters, whereas no significant differences were noted in cooked samples. In a study by Hayes et al. (2013), pork luncheon rolls containing $50 \mathrm{mg} / \mathrm{kg}$ nitrite and $1.5 \%$ tomato powder were characterised by identical or enhanced sensory attributes in comparison with samples without tomato powder that contained $100 \mathrm{mg} / \mathrm{kg}$ nitrite. The above results suggest that the nitrite content of processed meats could be reduced by $50 \%$ to deliver greater health benefits for consumers. Increased addition of tomato pulp powder (3\%) deteriorated the sensory quality of pork luncheon rolls. García et al. (2009) used dry tomato peels to produce hamburgers with a different lycopene content $(1.5,3$, 4.5 and $6 \%$ ). Hamburgers containing $4.5 \%$ lycopene were characterised by satisfactory sensory quality. The highest lycopene content lowered the scores for taste, overall acceptability and texture of the analysed hamburgers.

The addition of lycopene-containing tomato peel extract lowered the $\mathrm{pH}$ of the water homogenate. According to Eyiler \& Oztan (2011), it was most probably related to the acidic characteristics of the tomato powder ( $\mathrm{pH}$ 4.48-5.02). Similar results were reported by Eyiler \& Oztan (2011), because frankfurters produced without tomato powder were characterised by higher $\mathrm{pH}_{\mathrm{u}}$ (6.30) than frankfurters containing this lycopene source (an average of 6.12). The cited authors reported a decrease in $\mathrm{pH}_{u}$ (by 0.13 and 0.24 units, respectively) with increasing inclusion levels of tomato powder (2 and $4 \mathrm{~g} / 100 \mathrm{~g}$ ). Yılmaz et al. (2002) analysed the acidity of 7 types of cooked low-fat sausages and concluded that the addition of tomato juice significantly influenced $\mathrm{pH}_{\mathrm{u}}$. Excluding sausages with a reduced beef content, a significant decrease $(p<0.05)$ in $\mathrm{pH}_{u}$ values was observed in all samples 
after the addition of tomato juice. A drop in $\mathrm{pH}_{\mathrm{u}}$ values of meat products containing tomato paste was also reported by Candogan (2002) and Deda et al. (2007). The discussed changes can probably be attributed to the acidity of tomatoes and high concentrations of the added component. According to Calvo et al. (2008), the addition of various amounts of dry tomato peel during the production of dry fermented sausages did not affect the products' $\mathrm{pH}_{u}$ values on storage days 0 and 21. It should be noted that the content of dry tomato peel tested by the above authors (up to 1.2\%) was much lower than in the previously cited studies. Sánchez-Escalante et al. (2003) used hot cayenne pepper, sweet red pepper, lycopene-rich tomato pulp and extract in the production of beef patties. Regardless of their concentrations, the applied antioxidants had no significant influence on the $\mathrm{pH}$ of meat measured in a water homogenate.

Colour is one of the most important indicators of meat quality for consumers, and it can be altered and fixed with the use of additives and colourings. In this experiment, lycopene had a highly significant influence $(p \leq 0.01)$ on the majority of tested colour parameters, both on the surface and along the crosssection of processed meat products from experimental group II. Lycopene increased the darkness of meat colour and the contribution of redness, which increased colour saturation (chroma) and hue values in the analysed samples. The surfaces of final products were characterised by lower lightness (63.17 on average) and higher yellowness (27.86 on average), as compared with the cross-sections (78.24 and 15.45, respectively). This was due to the fact that Maillard reaction products had formed on the product's surface during thermal processing (Modzelewska-Kapituła, 2012). According to Calvo et al. (2008), the addition of dry tomato peel significantly $(p<0.05)$ influenced the colour of salchichóns (dry fermented sausages). Control group sausages were characterised by the lightest colour, the lowest share of components $a^{*}$ and $b^{*}$, and, consequently, the lowest values of coordinates $C^{*}$ and $h^{\circ}$. In a study by García et al. (2009), the addition of dry tomato peel to beef hamburgers lowered the value of parameter $L^{*}$ and increased the contribution of redness and yellowness in comparison with control samples. Similar changes were reported by Candogan (2002) in beef patties containing tomato paste. According to Østerlie \& Lerfall (2005), colour is a very important quality parameter of ground meat and meat stuffings used industrially and at home. Those products are highly susceptible to spoilage, microbial activity, physiological and chemical changes, which is why they rapidly lose their original colour even after a short period of storage. In the above study, ground beef with the addition of tomato peel and tomato powder was characterised by greater colour stability during cold storage. In our experiment, lycopene improved colour stability only along the cross-section of the analysed meat samples. Doménech-Asensi et al. (2013) demonstrated that mortadella containing tomato powder (TP) was characterised by higher values of the colour stability coefficient $(\Delta \mathrm{E})$ after two months of storage at $4^{\circ} \mathrm{C}$. A statistical analysis revealed that the addition of TP had only a minor influence on colour parameters in both analysed groups. No significant differences in lightness $\left(L^{*}\right)$, contribution of redness $\left(a^{*}\right)$ or chroma $\left(C^{*}\right)$ were observed between groups, whereas the values of component $b^{*}$ and hue differed significantly $(p<0.05)$. According to Calvo et al. (2008), this could be due to the loss of lycopene during ripening. It is a well-known fact that inadequate storage of tomato peel can change its colour from red to orange due to the oxidation of carotenoids, mainly lycopene. The authors observed a red colour when meat was mixed with dry tomato peel. However, after 21 days of ripening, the changes in tomato peel colour described above could mask the natural red colour of sausages with a tendency to an orange colour. Doménech-Asensi et al. (2013) demonstrated that the addition of lycopene to meat products, through the addition of tomato peel and tomato powder, led to changes in the typical red colour of meat products by increasing the yellow colour and providing an orange tone. According to Eyiler \& Oztan (2011), tomato powder can be successfully used as a colouring in sausage production. The above authors argued that nitrites can be partially replaced with natural additives without compromising the shelf-life of sausages. Nitrite concentrations can be lowered to $50 \mathrm{mg} / \mathrm{kg}$ by adding $4 \mathrm{~g} / 100 \mathrm{~g}$ of tomato powder, but a combination of $100 \mathrm{mg} / \mathrm{kg}$ of nitrites and $2 \mathrm{~g} / 100 \mathrm{~g}$ of tomato powder delivered products with higher antioxidant properties and a more acceptable colour.

It can be concluded that the addition of tomato peel extract to turkey breast muscles during the production process affected the concentrations of vitamins $E$ and $A$, as well as selected sensory attributes and physicochemical properties of the final products. The addition of lycopene-containing tomato peel extract lowered the $\mathrm{pH}$ of the water homogenate. Lycopene improved colour parameters which play an important role in the production, distribution and consumer 
acceptability of meat products. Lycopene increased colour darkness on the surface and along the crosssection of the analysed products, and the contribution of redness. The values of parameters $L^{*}$ and $a^{*}$ corresponded to the increase in colour saturation and the decrease in hue. A sensory analysis revealed that lycopene lowered average scores for the aroma and flavour of processed turkey breast muscles, which can probably be attributed to the natural acidity and specific taste of tomatoes.

\section{ACKNOWLEDGMENTS}

This study was supported by the European Union within the European Social Fund.

\section{REFERENCES}

Akdemir F, Orhan C, Sahin N, Sahin K, Hayirli A. Tomato powder in laying hen diets: effects on concentrations of yolk carotenoids and lipid peroxidation. British Poultry Science 2012;53(5):675-680.

Baryłko-Pikielna N, Matuszewska I. Sensory investigation of food. Basics methods - applications. Kraków: PTTŻ Scientific Press; 2009.

Batkowska J, Brodacki A. Physico-chemical traits of meat from slaughter turkey females, kept in extensive management system. Scientific Annals of Polish Society of Animal Production 2011;7(1):39-49.

Calvo MM, García ML, Selgas MD. Dry fermented sausages enriched with lycopene from tomato peel. Meat Science 2008;80:167-172.

Candogan $\mathrm{K}$. The effect of tomato paste on some quality characteristics of beef patties during refrigerated storage. European Food Research and Technology 2002;215:305-309.

Chen J, Shi J, Xue SJ, Ma Y. Comparison of lycopene stability in waterand oil-based food model systems under thermal- and light-irradiation treatments. LWT- Food Science and Technology 2009;42:740-747.

CIE - Recommendations on uniform color spaces-color difference equations. Psychometric color terms [publication no. 15]. Paris: Commission Internationale de I'E A Clairage; 1978.

Deda MS, Bloukas JG, Fista GA. Effect of tomato paste and nitrite level on processing and quality characteristics of frankfurters. Meat Science 2007;76:501-508.

Doménech-Asensi G, García-Alonso FJ, Martínez E, Santaella M, MartínPozuelo G, Bravo S, et al. Effect of the addition of tomato paste on the nutritional and sensory properties of mortadella. Meat Science 2013;93:213-219

EC - European Commission. Regulation (EC) No 853/2004 of the European Parliament and of the Council of 29 April 2004 laying down specific hygiene rules for food of animal origin. 2004. Available from: http:// eur-lex.europa.eu/legal-content/EN/TXT/?uri=celex:32004R0853.

EC- European Commission. Council Regulation (EC) No 1099/2009 of 24 September 2009 on the protection of animals at the time of killing. 2009. Available from: http://eur-lex.europa.eu/LexUriServ/LexUriServ. do?uri=OJ:L:2009:303:0001:0030:EN:PDF

Englmaierová M, Bubancová I, Vít T, Skřivan M. The effect of lycopene and vitamin $\mathrm{E}$ on growth performance, quality and oxidative stability of chicken leg meat. Czech Journal of Animal Science 2011:56(12):536543

Eyiler E, Oztan A. Production of frankfurters with tomato powder as a natural additive. LWT - Food Science and Technology 2011;44:307311.

Fredriksson Eriksson S, Pickova J. Fatty acids and tocopherol levels in M. Longissimus dorsi of beef cattle in Sweden- A comparison between seasonal diets. Meat Science 2007;76(4):746-754.

García ML, Calvo MM, Selgas MD. Beef hamburgers enriched in lycopene using dry tomato peel as an ingredient. Meat Science 2009;83:45-49.

Gimeno E, Castellote Al, Lamuela-Raventós RM, de la Torre MC, LópezSabater MC. Rapid determination of vitamin $E$ in vegetable oils by reversed-phase high-performance liquid chromatography. Journal of Chromatography A 2000;881(1-2):251-254.

Hayes JE, Canonico I, Allen P. Effects of organic tomato pulp powder and nitrite level on the physicochemical, textural and sensory properties of pork luncheon roll. Meat Science 2013;95:755-762.

Honikel KO. Reference methods for the assessment of physical characteristics of meat. Meat Science 1998;49(4):447-457.

Hőgberg A, Pickova J, Babol J, Andersson K, Dutta PC. Muscle lipids, vitamins $E$ and $A$, and lipid oxidation as affected by diet and $R N$ genotype in female and castrated male Hampshire crossbreed pigs. Meat Science 2002;60(4):411-420

Hunt MC, Acton JC, Benedict RC, Calkins CR, Cornforth DP, Jeremiah LE, et al. Guidelines for meat color evaluation. Proceedings of the 44th Reciprocal Meat Conference; 1991 Jun 9-12; Kansas. USA. p. 1-17.

ISO- International Organization for Standardization. Sensory analysisGeneral guidance for the selection, training and monitoring of assessors- Part 2: Experts. Method ISO 8586-2. 1994

ISO- International Organization for Standardization. Sensory analysisGeneral guidance for the design of test rooms. Method ISO 8589 1998.

Karadas F, Grammenidis E, Surai PF, Acamovic T, Sparks NHC. Effects of carotenoids from lucerne, marigold and tomato on egg yolk pigmentation and carotenoid composition. British Poultry Science 2006a;47(5):561-566

Karadas F, Surai P, Grammenidis E, Sparks NHC, Acamovic T. Supplementation of the maternal diet with tomato powder and marigold extract: effects on the antioxidant system of the developing quail. British Poultry Science 2006b;47(2):200-208.

Kondratowicz J, Chwastowska-Siwiecka I, Burczyk E, Piekarska J, Kułdo Ż. Sensory \& microbiological assessment of turkey hens breast muscles depending on method and time of cold storage. Food Science. Technology. Quality 2011;3(76):143-152

Koprivnjak JF, Lum KR, Sisak MM, Saborowski R. Determination of $\alpha-$, $\gamma(+\beta)$-, and $\delta$-tocopherols in a variety of liver tissues by reverse-phase high pressure liquid chromatography. Comparative Biochemistry and Physiology Part B: Biochemistry and Molecular Biology 1996;113(1):143148.

Lipiński K, Kaliniewicz J, Tywończuk J, Stasiewicz M. The effect of probiotic and herbal additives on the productivity and meat quality of turkeys. Scientific Annals of Polish Society of Animal Production 2011;7(2):2935.

Litwińczuk Z. Animal materials-assessment and the use of. PWRiL Press Warszawa 2004. 
Maiani G, Castón MJ, Castana G, Toti E, Cambrodón IG, Bysted A, et al. Carotenoids: Actual knowledge on food sources intakes, stability and bioavailability and their protective role in humans. Molecular Nutrition \& Food Research 2009;53:5194-5218.

Mikulski D, Jankowski J, Zdunczyk Z, Juskiewicz J, Slominski BA. The effect of different dietary levels of rapeseed meal on growth performance, carcass traits, and meat quality in turkeys. Poultry Science 2012;91:215223.

Østerlie M, Lerfall J. Lycopene from tomato products added minced meat: Effect on storage quality and colour. Food Research International 2005;38:925-929.

Palka K. Changes in intramuscular connective tissue and collagen solubility of bovine $\mathrm{M}$. semitendinosus during retorting. Meat Science 1999:53:189-194.

Papaioannou EH, Karabelas AJ. Lycopene recovery from tomato peel under mild conditions assisted by enzymatic pre-treatment and non-ionic surfactants. Acta Biochimica Polonica 2012;1(59):71-74.

PN-A- Polski Komitet Normalizacyjny. Produkty rolniczo-żywnościoweOznaczanie azotu metodą Kjeldahla i przeliczanie na białko (Polish Standard- Polish Committee for Standardization. Agricultural Food Products- Determination of nitrogen by the Kjeldahl method and expressing as protein; in Polish). Method PN-A 04018:1975/Az3. 2002.

PN-ISO- Polski Komitet Normalizacyjny. Analiza sensoryczna- MetodologiaOcena produktów żywnościowych przy użyciu metod skalowania (Polish Standard- Polish Committee for Standardization. Sensory analysis- Methodology- Evaluation of food products by methods using scales; in Polish). Method PN-ISO 4121. 1998.

PN-ISO- Polski Komitet Normalizacyjny. Mięso i przetwory mięsneOznaczanie popiołu całkowitego (Polish Standard- Polish Committee for Standardization. Meat and meat products- Determination of total ash; in Polish). Method PN-ISO 936. 2000a.

PN-ISO- Polski Komitet Normalizacyjny. Mięso i przetwory mięsneOznaczanie zawartości wody (metoda odwoławcza) (Polish StandardPolish Committee for Standardization. Meat and meat productsDetermination of moisture content (reference method); in Polish). Method PN-ISO 1442. 2000b.

PN-ISO- Polski Komitet Normalizacyjny. Mięso i przetwory mięsneOznaczanie zawartości tłuszczu wolnego (Polish Standard- Polish Committee for Standardization. Meat and meat productsDetermination of free fat content; in Polish). Method PN-ISO 1444. 2000c.

PN-ISO- Polski Komitet Normalizacyjny. Mięso i przetwory mięsneOznaczanie zawartości hydroksyproliny (Polish Standard- Polish Committee for Standardization. Meat and meat productsDetermination of hydroxyproline content; in Polish). Method PN-ISO 3496. 2000d

PN-ISO- Polski Komitet Normalizacyjny. Mięso i przetwory mięsne- Pomiar pH- Metoda odwoławcza (Polish Standard- Polish Committee for Standardization. Meat and meat products- Measurement of $\mathrm{pH}$ Method of Appeal.; in Polish). Method PN-ISO 2917:2001/Ap1. 2002.
Rao AV, Fleshner N, Agarwal S. Serum and tissue lycopene and biomarkers of oxidation in prostate cancer patients: a case-control study. Nutrition and Cancer 1999;33(2):159-164

Rozbicka-Wieczorek AJ, Więsyk E, Brzóska F, Śliwiński B, Kowalczyk J, Czauderna M. Fatty acid profile and oxidative stress of high muscles on chicken fed ration enriched in lycopene, selenium compounds or fish oil. Annals of Animal Science 2014;14:595-609.

Sánchez-Escalante A, Torrescano G, Djenane D, Beltrán JA, Roncalés P. Stabilisation of colour and odour of beef patties by using lycopene-rich tomato and peppers as a source of antioxidants. Journal of the Science of Food and Agriculture 2003;83:187-194.

Shi J, Le Maguer M. Lycopene in tomatoes: chemical and physical properties affected by food processing. Critical Reviews in Food Science and Nutrition 2000;40(1):1-42.

Sieczkowska H, Antosik K, Krzęcio-Nieczyporuk E, Zybert A, KoćwinPodsiadła M. Usefulness of selected parameters determined 45 minutes post mortem in longissimus lumborum muscle to evaluate pork quality. Food. Science. Technology. Quality 2013;2(87):51-60.

Savadkoohi S, Hoogenkamp H, Shamsi K, Farahnaky A. Color, sensory and textural attributes of beef frankfurter, beef ham and meat-free sausage containing tomato pomace. Meat Science 2014;97:410-418.

StatSoft. Statistica (data analysis software system). Version 10.0; 2011. Available from: www.stalsoft.com.

Vági $E$, Simándi $B$, Vásárhelyiné $K P$, Dado $H$, Kéry Á, Doleschall $F$, et al. Supercritical carbon dioxide extraction of carotenoids, tochopherols and sitosterols from industrial tomato by-products. Journal of Supercritical Fluids 2007;40:218-226.

Van Oeckel MJ, Warnants N, Boucqueé ChV. Comparison of different methods for measuring water holding capacity and juiciness of pork versus on-line screening methods. Meat Science 1999;51(4):313-320.

Werner C, Riegel J, Wicke M. Slaughter performance of four different turkey strains, with special focus on the muscle fiber structure and the meat quality of the breast muscle. Poultry Science 2008;87:1849-1859.

Wilkanowska A. Aspects of poultry meat quality. Poultry breeder 2011;12:16-22.

Xu F, Yuan QP, Dong HR. Determination of lycopene and $\beta$-carotene by high-performance liquid chromatography using sudan I as internal standard. Journal of Chromatography B 2006;838:44-49.

$\mathrm{Xu}$ Z. Comparison of extraction methods for quantifying vitamin $\mathrm{E}$ from animal tissues. Bioresource Technology 2008;99(18):8705-8709.

Yılmaz I, ŞimşekO, Işıklı M. Fatty acid composition and quality characteristics of low-fat cooked sausages made with beef and chicken meat, tomato juice and sunflower oil. Meat Science 2002;62:253-258.

Zybert A, Tarczyński K, Sieczkowska H, Koćwin-Podsiadła M. Glycolytic and energetic resources as the determinants of meat quality of Duroc fatteners. Journal of Central European Agriculture 2015;16(1):177187. 
